\title{
ПОЛОВАЯ АКТИВНОСТЬ И СПЕРМОПРОДУКЦИЯ У БАРАНОВ ПОРОД ШАРОЛЕ И ИЛЬ-ДЕ-ФРАНС В РАЗНЫЕ СЕЗОНЫ ГОДА
}

\author{
Т.В. МАМОНТОВА', М.И. СЕЛИОНОВА ${ }^{2}$, А.-М.М. АЙБАЗОВ 1
}

Овцы (Ovis aries) относятся к полиэстричным животным с четко выраженным половым сезоном. Длительный искусственный отбор способствовал минимизации воздействия сезонных факторов внешней среды на проявление репродуктивной функции у овец, однако в средних и высоких широтах сезонность их размножения хорошо выражена. Поскольку Россия не располагает генофондом высокопродуктивных специализированных мясных пород овец, неизбежно использование лучших пород зарубежной селекции. В настоящей работе в условиях центральной зоны Ставропольского края впервые установлен диапазон вариативности половой активности и спермопродукции у мясных баранов Шароле (Charollais) и Иль-де-Франс (île-de-France) в зависимости от сезона года. Наибольшая воспроизводительная активность выявлена в осенний период. Нашей целью было изучение сезонных колебаний половой активности и параметров спермопродукции у баранов (O. aries) мясных пород зарубежной селекции Шароле и Иль-де-Франс в условиях центральной зоны Ставропольского края. Исследования проводили с октября 2019 года по сентябрь 2020 года на опытной станции Всероссийского НИИ овцеводства и козоводства - филиала ФГБНУ Северо-Кавказский федеральный научный аграрный центр на племенных баранах-производителях мясных пород зарубежной селекции Шароле $(n=8)$ и Иль-де-Франс $(n=5)$. Сперму получали с помощью искусственной вагины. Половую активность, проявляемую одними и теми же баранами, учитывали по затрате времени на выделение одного эякулята, то есть по продолжительности проявления комплекса всех половых рефлексов (от запуска барана в манеж с зафиксированной в станке самкой до рефлекса эякуляции). Каждый эякулят оценивался по объему, подвижности и концентрации. Объем эякулята определяли с помощью градуированной пипетки или в градуированном одностенном семяприемнике. Подвижность спермиев оценивали под микроскопом Nikon Ts2R («Nikon», Япония) по 10-балльной шкале. Концентрацию спермиев определяли на фотометре Accucell («IMV Technologies», Франция) или подсчитывали в счетной камере Горяева под микроскопом, для чего сперму предварительно разбавляли в 200 раз 3 \% раствором хлористого натрия в эритроцитарном меланжере-смесителе. В зимний период половая активность снижалась, что выражалось в первую очередь увеличением времени, затрачиваемого на проявление комплекса половых рефлексов. Так, у баранов породы Шароле время на получение эякулята увеличивалось в 1,70 раза в зимние месяцы по сравнению с осенним периодом, а в весенние и летние месяцы соответственно в 2,56 и 2,62 раза. Бараны породы Иль-де-Франс показали аналогичную динамику, однако у них снижение половой активности было значительно менее выражено по сравнению с баранами Шароле. Так, в зимний период бараны Иль-де-Франс затрачивали в 1,09 раза больше времени на выделение эякулята, чем в половой сезон, а в весенний и летний периоды - соответственно в 1,62 и 1,78 раза болыше времени. У баранов породы Шароле подвижность спермы варьировала от 9,1 балла в половой сезон до 7,4 балла в весенний период. В зимний и летний периоды этот показатель составлял 8,5 и 8,1 балла. Аналогичные закономерности выявлены по отношению к объему спермы и концентрации спермиев: наибольшие значения были отмечены в осенний период, наименьшие - в весенний, промежуточные - в зимний и летний. У баранов породы Иль-де-Франс наибольшие показатели объема, концентрации и подвижности также были зарегистрированы в осенний период (соответственно 1,15 мл; 3,75 млрд/мл и 8,57 баллов), тогда как зимой эти параметры составили 0,98 мл; 3,38 млрд/мл и 7,95 баллов, весной - 0,88 мл; 2,85 млрд/мл и 7,55 баллов, летом - 0,96 мл; 3,15 млрд/мл и 8,19 баллов. Микроструктурный анализ показал, что количество спермиев с интактной акросомой колебалось от $65 \%$ летом (Шароле) до 82 \% в осенний период (Иль-де-Франс). Таким образом, несмотря на значительные сезонные вариации, бараныпроизводители пород Шароле и Иль-де-Франс в климатических условиях центральной зоны Ставропольского края способны продуцировать качественную сперму во все сезоны года.

Ключевые слова: бараны, половой сезон, неполовой сезон, половая активность, качество спермопродукции.

Овцеводство - одна из важнейших отраслей аграрного сектора экономики России. В дореформенный период (до 1990 года) рентабельность отрасли в стране составляла 30-50 \% и обеспечивалась государственной политикой в отношении производства тонкой шерсти. Однако прекращение государственной поддержки в рыночных условиях привело к убыточности 
этого производства. Начиная с 2001 года, стало понятно, что будущее отрасли зависит от развития мясного и отчасти молочного овцеводства. В овцеводческих странах вследствие многолетних рыночных традиций за последние десятилетия стремительно расширился ареал разведения существующих мясных пород овец, а также были выведены новые породы мясного и комбинированного направлений продуктивности (1).

Основная стратегия развития овцеводства в нашей стране в среднесрочной перспективе, по-видимому, также будет базироваться на экономической целесообразности производства молодой баранины и ягнятины. Однако в настоящее время Россия не располагает генофондом высокопродуктивных специализированных мясных пород, в полной мере отвечающих таким современным требованиям, как полицикличность, многоплодие, скороспелость, высокая энергия роста, отличные мясные качества. В связи с этим неизбежно использование лучших мясных пород зарубежной селекции в селекционных целях и для создания в регионах страны массивов мясных овец методом промышленного скрещивания с овцематками отечественных пород. Результативность широкого тиражирования генофонда баранов улучшающей породы в течение короткого времени в значительной степени будет зависеть от полноты реализации воспроизводительной функции терминальных производителей, их высокой половой активности и спермопродукции. Оптимальной методологией станет алгоритм, предусматривающий максимальное использование баранов в осенний половой сезон для осеменения овец свежеполученной и охлажденной транспортируемой спермой и накопление спермы в замороженном виде в остальные сезоны года (2-4).

Известно, что длительный искусственный отбор способствовал минимизации воздействия сезона на репродуктивную активность овец. Сезонность размножения слабо выражена или вообще не проявляется в породах, разводимых вблизи экватора, но распространена в средних и высоких широтах. Сезон размножения самок существенно короче, чем у самцов, и ограничен периодом с конца лета до января. Бараны также демонстрируют сезонные колебания половой активности и качества спермопродукции, однако их физиологическая волатильность менее выражена. На либидо и характеристику спермы баранов влияют многие факторы: порода, возраст, условия содержания и кормления, условия окружающей среды (фотопериод, инсоляция, температура, атмосферное давление, влажность и т.д.) (5-8). Кроме того, определенное значение имеют репродуктивный менеджмент, профессионализм техника по получению спермы, метод и частота отбора спермы (9-11).

Породы овец характеризуются различной фотореактивностью (12, 13). Получены интересные данные по сезонности и циркадным вариациям полового поведения баранов в тропических широтах (14). Так, уменьшение продолжительности светового дня увеличивает скорость сперматогенеза за счет выработки мелатонина, что стимулирует высвобождение гонадотропин-реализующих гормонов $(15,16)$.

Сезонные колебания спермопродукции (объема эякулята и концентрации спермиев), содержания тестостерона в крови и диаметра семенников были изучены в сухой и дождливый сезоны на 10 баранах породы Ouled Djellal, разводимых в районе Шлефа (17). Установлено, что диаметр тестикул, объем эякулята и концентрация спермиев изменяются так же, как уровень тестостерона в крови, количество которого характеризуется высокими значениями в осенне-зимний период и низким - в весенне-летний сезон. Эти результаты отражают наличие особого сезонного ритма функционирования гипофиза баранов изученной породы. 
J.A. Bravo с соавт. (18) выявили у баранов Иль-де-Франс наличие субпопуляций спермиев со специфическими характеристиками движения в свежеполученных эякулятах и определили изменения в структуре подвижных субпопуляций спермиев в разные сезоны года. С. Malejane с соавт. (19) сообщают о сезонной фертильности баранов наиболее распространенных в Южной Африке пород (включая породу Dorper), однако информация по этому вопросу очень ограничена.

В России экспериментальных данных о реализации воспроизводительной функции у мясных баранов зарубежной селекции крайне мало. Более того, фрагментарность и локальность экспериментов вызывают сомнения в их достоверности и исключают экстраполирование таких результатов в более широких масштабах.

В настоящей работе в условиях центральной зоны Ставропольского края впервые установлен диапазон вариативности половой активности и спермопродукции у мясных баранов Шароле и Иль-де-Франс в зависимости от сезона года. Наибольшая воспроизводительная активность выявлена в осенний период.

Нашей целью было изучение сезонных колебаний половой активности и параметров спермопродукции у баранов (Ovis aries) мясных пород зарубежной селекции Шароле и Иль-де-Франс в условиях центральной зоны Ставропольского края.

Методика. Исследования проводили с октября 2019 года по сентябрь 2020 года на опытной станции Всероссийского НИИ овцеводства и козоводства - филиала ФГБНУ Северо-Кавказский федеральный научный аграрный центр на племенных баранах-производителях мясных пород зарубежной селекции Шароле $(n=8)$ и Иль-де-Франс $(n=5)$.

Животные были завезены в октябре 2019 года из Великобритании. После 30-суточного карантина комплексно исследовали их половую активность и спермопродукцию. Всем баранам были обеспечены одинаковые условия содержания и ухода. Кормление осуществляли по рационам случного периода.

Сперму получали с помощью искусственной вагины. Половую активность, проявляемую одними и теми же баранами, учитывали по затрате времени на выделение одного эякулята, то есть по продолжительности проявления комплекса всех половых рефлексов - от запуска барана в манеж с зафиксированной в станке самкой до рефлекса эякуляции.

Каждый эякулят оценивали по объему, подвижности и концентрации (20). Объем эякулята определяли с помощью градуированной пипетки (до 0,1 мл) или в градуированном одностенном семяприемнике. Подвижность спермиев устанавливали под микроскопом Nikon Ts2R («Nikon», Япония) при увеличении $\times 200-× 400$ в нескольких полях зрения в капле спермы. Показатель подвижности оценивали по 10-балльной шкале. Концентрацию спермиев определяли на фотометре Accucell («IMV Technologies», Франция) или подсчитывали в счетной камере Горяева под микроскопом Nikon Ts2R при увеличении $\times 400$, для чего сперму предварительно разбавляли в 200 раз $3 \%$ раствором хлористого натрия в эритроцитарном меланжере-смесителе (ООО «ГЕН», Россия).

Продолжительность светового дня (ч) вычисляли как разницу между официальным временем восхода и захода солнца в каждые сутки эксперимента. Количество осадков (мм) и колебания температуры воздуха $\left({ }^{\circ} \mathrm{C}\right)$ регистрировали ежедневно. Для каждого параметра рассчитывали средние значения за сезон года.

Статистическую обработку проводили в программе Microsoft Excel 
2016. Результаты выражали как средние арифметические и стандартные отклонения $(M \pm \mathrm{SD})$. Для определения статистической значимости различий средних величин использовали $t$-критерий Стьюдента при трех условиях вероятности р и разных числах степеней свободы.

Результаты. Значительная часть территории опытной станции, на которой проводились опыты, расположена в пределах Ставропольской возвышенности на высоте 350-600 м над уровнем моря (Ставропольский край, Шпаковский р-н). Согласно многолетним данным Ставропольской метеорологической станции, район относится к зоне умеренного увлажнения. Важная особенность климата - быстрое повышение температуры весной и медленное понижение осенью. С середины апреля устанавливается безморозный период, который продолжается 175-180 сут. Лето довольно жаркое, со среднемесячной температурой $+20 \ldots+25^{\circ} \mathrm{C}$. Атмосферные засухи часто повторяются, и за летний период их продолжительность составляет около 60 сут. Только три месяца в году имеют среднюю температуру воздуха ниже $0{ }^{\circ} \mathrm{C}$, но даже в этот период часто наблюдаются оттепели. Снежный покров появляется в конце ноября - начале декабря. Сход снежного покрова происходит обычно в конце марта - начале апреля, период со снежным покровом и температурой воздуха ниже $0{ }^{\circ} \mathrm{C}$ насчитывает $90-95$ сут. В отдельные годы снежный покров отсутствует даже в зимний период. В год выпадает 550-600 мм осадков, преимущественно летом. Значительная их часть быстро испаряется от высоких температур и воздействия ветров-суховеев.

Средние параметры климатических данных по сезонам года за экспериментальный период представлены в таблице 1.

1. Климатологические данные экспериментального периода, в течение которого были изучены сезонные колебания половой активности и параметров спермопродукции у баранов (Ovis aries) пород Шароле и Иль-де-Франс (Ставропольский край, Шпаковский р-н, сентябрь 2019 года-август 2020 года)

\begin{tabular}{l|c|c|c|c}
\hline \multirow{2}{*}{ Сезон года } & \multicolumn{2}{|c|}{ Температура воздуха, ${ }^{\circ} \mathrm{C}$} & \multirow{2}{*}{ Количество осадков, мм } & $\begin{array}{l}\text { Средняя продолжитель- } \\
\text { ность светового дня, ч }\end{array}$ \\
\cline { 2 - 3 } & $\min$ & $\max$ & 97 & 10,8 \\
Осень & -3 & +29 & 109 & 9,2 \\
Зима & -12 & +18 & 77 & 13,8 \\
Весна & -9 & +22 & 46 & 14,7 \\
Лето & +15 & +35 &
\end{tabular}

Иль-де-франс - одна из наиболее популярных в мире мясных пород французской селекции, лидирующая в улучшении как материнских качеств овцематок, так и отцовских свойств баранов. Позиционируется как полицикличная порода, поэтому широко используется для интенсивного внесезонного производства ягнят и продукции пастбищных ягнят от ранневесенних окотов. Живая масса баранов, использованных в нашем эксперименте, колебалась от 100 до 125 кг. Они характеризовались хорошо развитыми мясными формами: имели широкую голову, короткую, широкую шею, округлые ребра, хорошо обмускуленные ляжки.

Шароле - мясошерстная порода французской селекции. Экспериментальные бараны имели живую массу от 105 до 140 кг и выраженные мясные формы: широкую голову, короткую, мощную шею, бочкообразное туловище с округлыми ребрами, отлично обмускуленные ляжки.

Многочисленные наблюдения и эксперименты, проведенные в средних широтах, доказали, что гаметогенез (овогенез) у овец практически прекращается в период с января по июль. Соответственно, у животных отсутствуют безусловные половые рефлексы (охота, течка, овуляция). Этот сезон принято называть неполовым, или анэстральным. При всей условности названия оно точно определяет физиологическое состояние овец (21). 
Напротив, у баранов большинства пород спермиогенез и секреция мужского полового гормона осуществляются непрерывно, в течение всего года. Это теоретически позволяет использовать их для получения спермы или случки круглогодично. Тем не менее практические наблюдения и многочисленные исследования показывают, что сезонные эколого-климатические факторы могут оказывать заметное влияние как на половую активность производителей, так и на качество выделяемой ими спермы $(15,22,23)$.

2. Активность половых рефлексов у баранов (Ovis aries) пород Шароле $(n=8)$ и Иль-де-Франс $(n=5)$ в зависимости от сезона года $(M \pm \mathrm{SD}$, Ставропольский край, Шпаковский р-н, сентябрь 2019 года-август 2020 года)

\begin{tabular}{|c|c|c|c|}
\hline Сезон года & Порода & Получено и исследовано эякулятов & $\begin{array}{l}\text { Время на получение } \\
\text { одного эякулята, с }\end{array}$ \\
\hline \multirow[t]{2}{*}{$\overline{\text { Осень }}$} & Шароле & 88 & $48,6 \pm 0,15$ \\
\hline & Иль-де-Франс & 40 & $88,5 \pm 0,19$ \\
\hline \multirow[t]{2}{*}{ Зима } & Шароле & 72 & $83,9 \pm 0,28 *$ \\
\hline & Иль-де-Франс & 36 & $96,5 \pm 0,35^{*}$ \\
\hline \multirow[t]{2}{*}{ Весна } & Шароле & 68 & $124,6 \pm 0,24 * *$ \\
\hline & Иль-де-Франс & 34 & $143,4 \pm 0,38 * *$ \\
\hline \multirow[t]{2}{*}{ Лето } & Шароле & 56 & $127,5 \pm 0,33^{* *}$ \\
\hline & Иль-де-Франс & 38 & $157,9 \pm 0,15^{* *}$ \\
\hline
\end{tabular}

3. Оценочная шкала подвижности спермиев у баранов (Ovis aries) пород Шароле и Иль-де-Франс

\begin{tabular}{|c|c|c|}
\hline Класс оценки & Баллы & Описание движения \\
\hline Отлично & $9-10$ & $\begin{array}{l}\text { Плотные, очень быстро движущиеся волны; от } 90 \text { \% и более спермиев } \\
\text { активны }\end{array}$ \\
\hline Хорошо & $7-8$ & $\begin{array}{l}\text { Энергичные волновые движения, но не так быстро, как при 9-10 } \\
\text { баллах; 70-85 \% спермиев активны }\end{array}$ \\
\hline Удовлетворительно & $5-6$ & $\begin{array}{l}\text { Только небольшие, медленно движущиеся волны; 45-65 \% спермиев } \\
\text { активны }\end{array}$ \\
\hline Неудовлетворительно & $3-4$ & $\begin{array}{l}\text { Волны не образуются, видно некоторое движение спермиев; 20-40 \% } \\
\text { спермиев живы, но с плохой подвижностью }\end{array}$ \\
\hline Плохо & $1-2$ & Около $10 \%$ спермиев проявляют признаки слабого движения \\
\hline Мертвая & 0 & Движения спермиев не наблюдается \\
\hline
\end{tabular}

Всего в разные сезоны года у баранов пород Шароле и Иль-деФранс мы получили 432 эякулята (табл. 2). Половая активность животных в разные сезоны оставалась высокой. У всех производителей были хорошо выражены локомоторная реакция на самку, зафиксированную в станке, комплекс ухаживания, обнимательный рефлекс и рефлекс эякуляции. Однако в скорости и интенсивности протекания этих процессов наблюдались значительные вариации в зависимости от сезона года. Тенденция к снижению половой активности проявлялась в зимний период, затем усиливалась в весенне-летний и выражалась в первую очередь увеличением времени на проявление всего комплекса половых рефлексов.

Так, у баранов Шароле время на получение эякулята в зимние месяцы по сравнению с осенними увеличилось в 1,7 раза, а в весенние и летние месяцы - соответственно в 2,56 и 2,62 раза $(\mathrm{p}<0,001)$. Бараны породы Иль-де-Франс показали аналогичную динамику активности половых рефлексов. В то же время снижение интенсивности либидо было значительно менее выражено по сравнению с баранами Шароле. В зимний период бараны Иль-де-Франс затрачивали на выделение одного эякулята в 1,09 раза больше времени, чем в половой сезон, в весенний и летний периоды соответственно в 1,62 и 1,78 раза больше времени $(\mathrm{p}<0,01)$. Следовательно, половая активность у баранов породы Иль-де-Франс была менее подвержена влиянию сезонных факторов, в отличие от производителей породы 
Шароле, которым для проявления полного комплекса рефлексов по выделению эякулята в весенний и летний периоды был необходим достоверно $(\mathrm{p}<0,001)$ больший промежуток времени.

Половая активность производителей имеет важное значение, однако для получения высокой результативности осеменения приоритетно качество спермопродукции. Мы исследовали объем, подвижность и концентрацию свежеполученной спермы по 284 эякулятам баранов породы Шароле и 148 эякулятам баранов породы Иль-де-Франс. Показатель подвижности спермы оценивался по 10-балльной шкале (табл. 3).

Параметры спермопродукции баранов обеих пород во все сезоны года оставались достаточно высокими и соответствовали требованиям (табл. 4). При этом были выявлены некоторые вариации.

4. Характеристика спермопродукции баранов (Ovis aries) пород Шароле $(n=8)$ и Иль-де-Франс $(n=5)$ в зависимости от сезона года $(M \pm \mathrm{SD}$, Ставропольский край, Шпаковский р-н, сентябрь 2019 года-август 2020 года)

\begin{tabular}{|c|c|c|c|}
\hline Показатель & Сезон & Шароле & Иль-де-Франс \\
\hline \multirow{4}{*}{ Объем, мл } & Осень & $1,2 \pm 0,15$ & $1,1 \pm 0,14$ \\
\hline & Зима & $1,0 \pm 0,11$ & $1,0 \pm 0,19$ \\
\hline & Весна & $0,9 \pm 0,17$ & $0,9 \pm 0,12$ \\
\hline & Лето & $1,0 \pm 0,19$ & $1,0 \pm 0,14$ \\
\hline \multirow[t]{4}{*}{ Концентрация, млрд/мл } & Осень & $3,8 \pm 0,15$ & $3,7 \pm 0,20$ \\
\hline & Зима & $3,3 \pm 0,18$ & $3,4 \pm 0,27$ \\
\hline & Весна & $2,9 \pm 0,12$ & $2,8 \pm 0,39$ \\
\hline & Лето & $2,9 \pm 0,19$ & $3,1 \pm, 022$ \\
\hline \multirow{4}{*}{$\begin{array}{l}\text { Подвижность свежеполученной } \\
\text { спермы, балл }\end{array}$} & Осень & $9,1 \pm 0,53$ & $8,6 \pm 0,56$ \\
\hline & Зима & $8,5 \pm 0,46$ & $8,0 \pm 0,73$ \\
\hline & Весна & $7,4 \pm 0,59$ & $7,5 \pm 0,54$ \\
\hline & Лето & $8,1 \pm 0,63$ & $8,2 \pm 0,62$ \\
\hline \multirow{4}{*}{$\begin{array}{l}\text { Количество спермиев с интактной } \\
\text { акросомой, \% }\end{array}$} & Осень & $78,0 \pm 2,29$ & $82,0 \pm 3,84$ \\
\hline & Зима & $75,0 \pm 3,43$ & $78,0 \pm 2,56$ \\
\hline & Весна & $68,0 \pm 2,18$ & $75,0 \pm 3,17$ \\
\hline & Лето & $65,0 \pm 2,26$ & $72,0 \pm 2,89$ \\
\hline
\end{tabular}

У баранов породы Шароле подвижность спермы варьировала от 9,1 в половой сезон до 7,4 балла в весенний период, когда наблюдалось наименьшее значение этого показателя. В зимний и летний периоды подвижность составляла 8,5 и 8,1 балла. Объем спермы и концентрация спермиев также имели наименьшие значения в весенний период, тогда как в зимний и летний занимали промежуточное положение.

Качество и количество спермопродукции у баранов породы Иль-деФранс имели высокую вариабельность в зависимости от сезона получения спермы. Наибольшие показатели объема, концентрации и подвижности были в осенний период (соответственно 1,15 мл, 3,75 млрд/мл и 8,57 баллов), тогда как зимой эти параметры составили 0,98 мл, 3,38 млрд/мл и 7,95 баллов, весной - 0,88 мл, 2,85 млрд/мл и 7,55 баллов, в летний период 0,96 мл, 3,15 млрд/мл и 8,19 баллов.

Снижение качественных показателей спермы сопровождалось увеличением микроструктурных повреждений и аномалий спермиев. Количество спермиев с интактной акросомой колебалось от $65 \%$ летом у баранов Шароле до 82 \% в осенний период у животных породы Иль-де-Франс.

Анализ полученных данных позволяет сделать предварительный вывод о том, что, несмотря на существенную волатильность, бараны-производители пород Шароле и Иль-де-Франс в климатических условиях центральной зоны Ставропольского края могут использоваться для получения высококачественной спермы во все сезоны года. Наивысшие показатели мы наблюдали в осенний половой сезон, что было прогнозируемым закономерным результатом. При этом низкие параметры в весенний 
период оказались достаточно неожиданным фактом. В весенний сезон фотопериод (длина светового дня) примерно такой же, как и в осенний, средняя температура окружающей среды, длительность инсоляции и влажность аналогичны среднеосенним показателям. Наоборот, в летний период все указанные климатические показатели, кроме влажности, достигают наивысших значений, однако летом спермопродукция у баранов оказалась существенно выше, чем весной. По-видимому, зимний и летний периоды относятся к переходным, а весенний, который отличается от осеннего только по одному природному показателю, служит антагонистом половому сезону. Если наше предположение корректно, то в реализации половой функции главную роль играют не абсолютные климатические показатели (фотопериод, температура, инсоляция), а позитивная динамика светового дня, то есть увеличивающийся фотопериод. Косвенное подтверждение этим выводам мы нашли в работах зарубежных коллег (22-25), однако для более обоснованного утверждения нужны дополнительные исследования.

Полученные данные по динамике основных параметров спермопродукции в разрезе пород мы считаем исключительно важными для принятия оптимального алгоритма работы с баранами пород Шароле и Идь-де-Франс с целью получения помесного молодняка. В то же время представлялось интересным изучить индивидуальные различия производителей по спермопродукции в рамках одной породы, что может дать теоретический и практический материал по лимитирующим параметрам основных показателей количества и качества спермы.

Репрезентативную выборку по баранам мы посчитали достаточной для выявления закономерности или хотя бы тенденции (табл. 5).

5. Индивидуальные параметры спермопродукции баранов (Ovis aries) пород Шароле и Иль-де-Франс ( $M \pm \mathrm{SD}$, Ставропольский край, Шпаковский р-н, сентябрь 2019 года-август 2020 года)

\begin{tabular}{|c|c|c|c|c|c|c|}
\hline \multirow[b]{2}{*}{ Порода } & \multirow[b]{2}{*}{ № барана } & \multirow[b]{2}{*}{$\begin{array}{l}\text { Исследовано } \\
\text { эякулятов, } n\end{array}$} & \multicolumn{3}{|c|}{ Характеристика спермопродукции } & \multirow{2}{*}{$\begin{array}{l}\text { Общее чис- } \\
\text { ло спермиев } \\
\text { с ППД в } \\
\text { эякуляте }\end{array}$} \\
\hline & & & $\begin{array}{l}\text { подвижность, } \\
\text { балл }\end{array}$ & объем, мл & $\begin{array}{l}\text { концентра- } \\
\text { ция, млрд/мл }\end{array}$ & \\
\hline \multirow[t]{8}{*}{ Шароле } & 06894 & 35 & $9,1 \pm 0,73$ & $1,1 \pm 0,13$ & $3,1 \pm 0,32$ & $3,2 \pm 0,18$ \\
\hline & 06943 & 30 & $8,2 \pm 0,83$ & $1,0 \pm 0,22$ & $3,2 \pm 0,30$ & $2,8 \pm 0,21$ \\
\hline & 01181 & 38 & $7,8 \pm 0,70$ & $0,9 \pm 0,09$ & $3,0 \pm 0,10$ & $2,1 \pm 0,09$ \\
\hline & 06947 & 34 & $8,3 \pm 0,44$ & $1,1 \pm 0,14$ & $3,1 \pm 0,13$ & $2,8 \pm 0,16$ \\
\hline & 06860 & 36 & $7,7 \pm 0,77$ & $1,0 \pm 0,21$ & $3,2 \pm 0,32$ & $2,5 \pm 0,12$ \\
\hline & 06917 & 40 & $8,5 \pm 0,53$ & $1,1 \pm 0,19$ & $2,8 \pm 0,23$ & $2,6 \pm 0,14$ \\
\hline & 01011 & 36 & $8,1 \pm 0,49$ & $1,0 \pm 0,17$ & $2,9 \pm 0,36$ & $2,3 \pm 0,11$ \\
\hline & 01029 & 35 & $7,6 \pm 0,87$ & $0,9 \pm 0,22$ & $3,1 \pm 0,22$ & $2,1 \pm 0,18$ \\
\hline \multicolumn{2}{|c|}{ Итого по породе $(n=8)$ : } & 284 & $8,2 \pm 0,45$ & $1,0 \pm 0,08$ & $3,0 \pm 0,12$ & $2,5 \pm 0,20$ \\
\hline \multirow[t]{5}{*}{ Иль-де-Франс } & 01121 & 32 & $9,0 \pm 0,53$ & $1,2 \pm 0,23$ & $3,4 \pm 0,31$ & $3,7 \pm 0,21$ \\
\hline & 01126 & 27 & $8,8 \pm 0,68$ & $1,2 \pm 0,13$ & $3,5 \pm 0,37$ & $3,6 \pm 0,26$ \\
\hline & 01132 & 29 & $7,9 \pm 0,88$ & $1,1 \pm 0,22$ & $3,1 \pm 0,41$ & $2,6 \pm 0,12$ \\
\hline & 01111 & 26 & $7,8 \pm 0,61$ & $1,1 \pm 0,21$ & $3,4 \pm 0,30$ & $2,8 \pm 0,14$ \\
\hline & 04511 & 34 & $8,4 \pm 0,77$ & $1,1 \pm 0,19$ & $3,3 \pm 0,33$ & $3,0 \pm 0,21$ \\
\hline \multicolumn{2}{|c|}{ Итого по породе $(n=5)$ : } & 148 & $8,4 \pm 0,33$ & $1,1 \pm 0,09$ & $3,4 \pm 0,16$ & $3,1 \pm 0,19$ \\
\hline p vitio & + & нейно & bHoe & & & \\
\hline
\end{tabular}

По результатам эксперимента были выявлены как внутрипородные индивидуальные различия между баранами, так и межпородные вариации. У животных породы Шароле подвижность спермы в среднегодовом выражении составила 8,16 баллов при вариативности показателя между производителями от 7,60 до 9,10 балла. Такая же высокая волатильность наблюдалась и по объему и концентрации спермы: при средних показателях 1,02 мл и 3,03 млрд/мл вариативность составила соответственно от 0,85 до 1,12 мл и от 2,75 до 3,22 млрд/мл. Один из ключевых параметров - общее число спермиев с прямолинейно-поступательным движением (ППД) в 
эякуляте - при среднем значении 2,53 млрд варьировало более чем с $50 \%$ амплитудой: от 2,09 до 3,18 млрд.

У баранов Иль-де-Франс волатильность подвижности составляла от 7,8 до 9,0 баллов при среднем показателе 8,38 балла. Объем спермы варьировал от 1,06 до 1,2 мл при среднем показателе 1,12 мл, концентрация - от 3,10 до 3,52 млрд/мл при среднем значении 3,34 млрд/мл. Как интегральное следствие этих трех параметров, общее количество спермиев с ППД составило в среднем 3,14 млрд при лимите от 2,62 до 3,67 млрд.

Снижение качества спермы в жаркое время года в некоторой степени объясняется повышением температуры мошонки и, как следствие, дегенерацией семенников под воздействием высоких температур окружающей среды $(26,27)$. Это также может привести к бесплодию или субфертильности $(28,29)$. Существуют исследования $(30,31)$, доказывающие, что повышение внешней температуры влияет на абсолютную температуру в различных областях семенников, тем самым определяя качество спермы и фертильность животных, выращиваемых на пастбищах.

В настоящем исследовании было выявлено, что у баранов Шароле и Иль-де-Франс в анэстральный период происходило снижение концентрации и общего количества спермиев. Различия в половой активности и параметрах спермопродукции в зависимости от сезона года в разных природно-климатических зонах были продемонстрированы в ряде зарубежных исследований (32-36).

Так, в работе S.A. Ibrahim (32) от 10 баранов было исследовано в общей сложности 900 эякулятов спермы. Самая качественная сперма была получена зимой (объем - 0,77 мл, $\mathrm{pH}-6,95$, подвижность - 4,53 балла по 5-балльной шкале, концентрация спермиев - 4932,72×106/мл), однако авторы оценивают качество спермы как хорошее во все сезоны года. При этом сезон года оказывал достоверное $(\mathrm{p}<0,01)$ влияние на половое поведение баранов: самая высокая половая активность была зарегистрирована осенью, самая низкая - летом. A. Benmoula с соавт. (33) оценивали сперму от пяти взрослых баранов INRA180 (возраст 2-3 года). Окружность мошонки, качество спермы и концентрация общего белка в семенной плазме оставались относительно постоянными в течение года $(\mathrm{p}>0,05)$. Не было зарегистрировано различий и в отношении общей подвижности спермиев (p >0,05), в то время как единственными параметрами, демонстрирующими сезонные колебания, оказались содержание холестерина, общих липидов в сперме и прогрессивная подвижность спермиев. O.I. Azawi с соавт. (34) исследовали образцы спермы от шести половозрелых баранов породы авасси. Больший $(\mathrm{p}<0,05)$ объем спермы отмечали в августе $(1,55 \pm 0,08$ мл) и марте $(1,27 \pm 0,15$ мл). Концентрация спермиев была самой высокой $(\mathrm{p}<0,05)$ в сезон размножения в сентябре $\left(4,21 \pm 0,86 \times 10^{9}\right.$ спермиев/мл). Индивидуальная подвижность спермиев и процент живых гамет, наблюдаемые в августе и мае, имели самые высокие значения и отличались $(\mathrm{p}<0,05)$ от таковых в декабре и январе.

Напротив, исследования Т. Tomkins с соавт. (35) показали, что осенью объем эякулята и процент живых спермиев снижался, а процент аномальных спермиев увеличивался, в то время как концентрация спермиев в эякуляте демонстрировала большее снижение летом. S. Belkadi с соавт. (36) выявили, что половая активность баранов была высокой в сезоны спаривания (весна и осень), что, по-видимому, детерминировано высоким со-

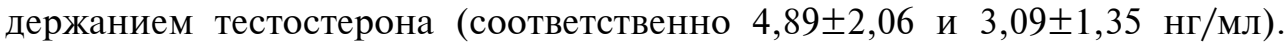
Средние значения объема эякулята, общей подвижности, количества живых спермиев и окружности мошонки были выше в весенний период 


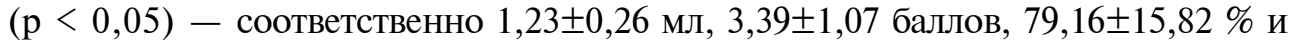
$36,29 \pm 1,91$ см, концентрация спермиев - в осенний $\left(1,19 \pm 0,56 \times 10^{9}\right.$ спермиев/мл по сравнению с $0,46 \pm 0,13 \times 10^{9}$ спермиев/мл весной).

Таким образом, либидо и гаметогенез у баранов зарубежной селекции Шароле и Иль-де-Франс в условиях центральной зоны Ставропольского края остаются высокими во все сезоны года. При этом для обеих пород отмечены широкие сезонные вариации в показателях половой активности и спермопродукции. Лучшую по качеству и объему сперму бараны продуцировали в осенний (половой) сезон. В другие сезоны года спермопродукция по основным параметрам также соответствовала инструктивным требованиям, хотя наблюдалась устойчивая тенденция к снижению объема, концентрации и подвижности спермиев. Уменьшение этих показателей в зимний период по отношению к осеннему оказалось наибольшим (в 1,52,0 раза). Следовательно, у баранов указанных пород сперматогенез происходит непрерывно во все сезоны года и их сперму можно круглогодично получать и использовать либо для осеменения маток, либо для заготовки в замороженном виде с целью длительного хранения.

\section{Л ИТ Р РАТ УРА}

1. Mazinani M., Rude B. Population, world production and quality of sheep and goat products. American Journal of Animal and Veterinary Sciences, 2020, 15(4): 291-299 (doi: 10.3844/ajavsp.2020.291.299).

2. Zamiri M.J., Khalili B., Jafaroghli M., Farshad A. Seasonal variation in seminal parameters, testicular size and plasma testosterone concentration in Iranian Moghani rams. Small Ruminant Research, 2010, 94(1-3): 132-136 (doi: 10.1016/j.smallrumres.2010.07.013).

3. Айбазов М.М., Трубникова П.В., Коваленко Д.В. Воспроизводительные функции баранов австралийской селекции в адаптационном аспекте. Зоотехния, 2007, 5: 29-30.

4. Мамонтова Т.В., Айбазов М.М. Оплодотворяющая способность спермы баранов разного срока хранения. Сельскохозяйственный журнал, 2017, 1(10): 186-190.

5. Reproduction in farm animals. 7th edition /B. Hafez, E.S.E. Hafez (eds.). Lippincott Williams and Wilkins, USA, 2000.

6. Karagiannidis A., Varsakeli S., Alexopoulos C., Amarantidis I. Seasonal variation in semen characteristics of Chios and Friesian rams in Greece. Small Ruminant Research, 2000, 37(1-2): 125130 (doi: 10.1016/S0921-4488(99)00143-1).

7. Chella L., Kunene N., Lehloenya K. A comparative study on the quality of semen from Zulu rams at various ages and during different seasons in KwaZulu-Natal, South Africa. Small Ruminant Research, 2017, 151: 104-109 (doi: 10.1016/j.smallrumres.2017.04.003).

8. Мамонтова Т.В., Айбазов М.М., Сеитов М.С. Сравнительная характеристика половой активности, уровня спермопродукции и устойчивости к криоконсервации спермы баранов различных пород. Известия Оренбургского государственного аграрного университета, 2018, 1(69): 145-147.

9. Talebi J., Souri M., Moghaddam A., Karimi I., Mirmahmoodi M. Characteristics and seasonal variation in the semen of Markhoz bucks in western Iran. Small Ruminant Research, 2009, 85(1): 18-22 (doi: 10.1016/j.smallrumres.2009.06.017).

10. Francis J.R., Javvaji P.K., Dhali A., Kolte A.P., Roy S.C., Giridhar K., Sejian V. Seasonal variations in quality, preservability and fertilizing ability of ovine spermatozoa. Biological Rhythm Research, 2020, 51(6): 951-962 (doi: 10.1080/09291016.2019.1566988).

11. Bonato M., Smith M.A.M.J., Malecki I.A., Cloete S.W.P. The effect of dilution rate and successive semen collections on sperm quality and sexual motivation of sexually mature South African Merino rams. Tropical Animal Health and Production, 2021, 53(1): 182 (doi: 10.1007/s11250-02102627-0).

12. Cardozo J.A., Fernández-Juan M., Forcada F., Abecia A., Muico-Blanco T., Cebrián-Pérez J.A. Monthly variations in ovine seminal plasma proteins analyzed by two-dimensional polyacrylamide gel electrophoresis. Theriogenology, 2006, 66(4): 841-850 (doi: 10.1016/j.theriogenology.2006.01.058).

13. Dupont J., Scaramuzzi R.J., Reverchon M. The effect of nutrition and metabolic status on the development of follicles, oocytes and embryos in ruminants. Animal, 2014, 7: 1-14 (doi: 10.1017/S1751731114000937).

14. Pourseif M.M., Moghaddam G.H. Photoperiod as a factor for studying fluctuations of seminal traits during breeding and non-breeding seasons. Journal of Cell and Animal Biology, 2012, 6(16): 241-249 (doi: 10.5897/JCAB12.052). 
15. Ntemka A., Kiossis E., Boscos C., Theodoridis A., Kourousekos G., Tsakmakidis I. Impact of old age and season on Chios ram semen quality. Small Ruminant Research, 2019, 178: 15-17 (doi: 10.1016/j.smallrumres.2019.07.004).

16. Ridler A.L., Smith S.L., West D.M. Ram and buck management. Animal Reproduction Science, 2012, 130(3-4): 180-183 (doi: 10.1016/j.anireprosci.2012.01.012).

17. Taherti M., Kaidi R., Aggad H. Monthly variations of the sexual activity of the ewe Ouled Djellal raised in the region of Chlef, Algeria [Variations mensuelles de l'activité sexuelle de la brebis ouled djellal élevée dans la région de Chlef, Algérie]. Livestock Research for Rural Development, 2016, 28(1): 3 .

18. Bravo J.A., Montanero J., Calero R., Roy T.J. Identification of sperm subpopulations with defined motility characteristics in ejaculates from Ile de France rams. Animal Reproduction Science, 2011, 129(1-2): 22-29 (doi: 10.1016/j.anireprosci.2011.10.005).

19. Malejane C., Greyling J.P.C., Raito M.B. Seasonal variation in semen quality of Dorper rams using different collection techniques. South African Journal of Animal Science, 2014, 44: 26-37 (doi: 10.4314/sajas.v44i1.4).

20. Инструкция по технологии работы организаций по искусственному осеменению и трансплантации эмбрионов сельскохозяйственных животных [Instructions on the technology of organizations for artificial insemination and embryo transplantation of farm animals]. Peжим доступа: http://old.mcx.ru/documents/document/v7_show/6295.191.htm. Дата обращения: 26.12.2003.

21. Habeeb H.M.H., Kutzler M.A. Estrus synchronization in the sheep and goat. Veterinary Clinics of North America: Food Animal Practice, 2021, 37(1): 125-137 (doi: 10.1016/j.cvfa.2020.10.007).

22. Sarlós P., Egerszegi I., Balogh O., Molnár A., Cseh S., Rátky J. Seasonal changes of scrotal circumference, blood plasma testosterone concentration and semen characteristics in Racka rams. Small Ruminant Research, 2013, 111(1-3): 90-95 (doi: 10.1016/j.smallrumres.2012.11.036).

23. Kulaksiz R., Sen C. Investigation of the changes observed in scrotal circumference and native and post-thaw semen characteristics in Karayaka rams during the breeding and nonbreeding seasons. Journal of the Hellenic Veterinary Medical Society, 2019, 70(3): 1655-1660 (doi: 10.12681/jhvms.21789).

24. Abecia J.A., Mura M.C., Carvajal-Serna M., Pulinas L., Macías A., Casao A., Pérez-Pe R., Carcangiu V. Polymorphisms of the melatonin receptor 1A (MTNR1A) gene influence the age at first mating in autumn-born ram-lambs and sexual activity of adult rams in spring. Theriogenology, 2020, 157: 42-47 (doi: 10.1016/j.theriogenology.2020.07.030).

25. Mandiki S.N.M., Derycke G., Bister J.L., Paquay R. Influence of season and age on sexual maturation parameters in Texel, Suffolk and Ile-de-France rams. 2. Circulating concentrations of FSH, LH, PRL and Testosterone. Small Ruminant Research, 1998, 28(1): 67-79.

26. Kahwage P.R., Esteves S.N., Jacinto M.A.C., Juniorb W.B., Machado R., Romanello N., Passeri L.F., Mendonça K.L., Garcia A.R. Assessment of body and scrotal thermoregulation and semen quality of hair sheep rams throughout the year in a tropical environment. Small Ruminant Research, 2018, 160: 72-80 (doi: 10.1016/j.smallrumres.2018.01.015).

27. Rasooli A., Taha Jalali M., Nouri M., Mohammadian B., Barati F. Effects of chronic heat stress on testicular structures, serum testosterone and cortisol concentrations in developing lambs. Animal Reproduction Science, 2010, 117(1-2): 55-59 (doi: 10.1016/j.anireprosci.2009.03.012).

28. Garcia A.R. Conforto térmico na reprodução de bubalinos criados em condições tropicais. Brazilian Journal of Animal Reproduction, 2013, 37(2): 121-130.

29. Marai I.F.M., El-Darawany A.A., Fadiel A., Abdel-Hafez M.A.M. Physiological traits as affected by heat stress in sheep - a review. Small Ruminant Research, 2007, 71(1-3): 1-12 (doi: 10.1016/j.smallrumres.2006.10.003).

30. Lunstra D.D., Coulter G.H. Coulter, relationship between scrotal infrared temperature patterns and natural-mating fertility in beef bulls. Journal of Animal Science, 1997, 75(3): 767-774 (doi: 10.2527/1997.753767x).

31. Menegassi S.R., Barcellos J.O., Dias E.A., Koetz C.Jr., Pereira G.R., Peripolli V., McManus C., Canozzi M.E., Lopes F.G. Scrotal infrared digital thermography as a predictor of seasonal effects on sperm traits in Braford bulls. International Journal of Biometeorology, 2015, 59(3): 357-364 (doi: 10.1007/s00484-014-0847-z).

32. Ibrahim S.A. Seasonal variations in semen quality of local and crossbred rams raised in the United Arab Emirates. Animal Reproduction Science, 1997, 49(2-3): 161-167 (doi: 10.1016/S03784320(97)00063-8).

33. Benmoula A., Badi A., El Fadili M., El Khalil K., Allai L., El Hilali A., El Amiri B. Effect of season on scrotal circumference, semen characteristics, seminal plasma composition and spermatozoa motility during liquid storage in INRA180 rams. Animal Reproduction Science, 2017, 180: 17-22 (doi: 10.1016/j.anireprosci.2017.02.008).

34. Azawi O.I., Ismaeel M.A. Effects of seasons on some semen parameters and bacterial contamination of Awassi ram semen. Reproduction in Domestic Animals, 2012, 47(3): 403-416 (doi: 10.1111/j.1439-0531.2011.01888.x). 
35. Tomkins T., Bryant M.J. Influence of mating pressure and season on the semen characteristics of rams. Animal Science, 1976, 22(3): 371-378 (doi: 10.1017/S0003356100035649).

36. Belkadi S., Safsaf B., Heleili N., Tlidjane M., Belkacem L., Oucheriah Y. Seasonal influence on sperm parameters, scrotal measurements, and serum testosterone in Ouled Djellal breed rams in Algeria. Veterinary World, 2017, 10(12): 1486-1492 (doi: 10.14202/vetworld.2017.1486-1492).

\title{
1ФГБНУ Северо-Кавказский федеральный научный аграрный центр, \\ Поступила в редакцию
}

355002 Россия, г. Ставрополь, пер. Зоотехнический, 15,

e-mail: mamontova.vniiok@gmail.com, velikii-1@yandex.ru $\square$;

2 ФГБОУ ВО Российский государственный

аграрный университет-МСХА им. К.А. Тимирязева,

127550 Россия, г. Москва, ул. Тимирязевская, 49,

e-mail: m_selin@mail.ru

Sel'skokhozyaistvennaya biologiya [Agricultural Biology], 2021, V. 56, № 4, pp. 752-762

\section{SEXUAL ACTIVITY AND SPERM PRODUCTION OF CHAROLAIS AND ILE-DE-FRANCE RAMS IN DIFFERENT SEASONS OF THE YEAR}

\author{
T.V. Mamontova1, M.I. Selionova ${ }^{2}$, A.-M.M. Aybazov ${ }^{1}$
}

${ }^{1}$ North Caucasus Federal Agrarian Research Centre, ul. 15, per. Zootechnicheskii, Stavropol, 355002 Russia, e-mail mamontova.vniiok@gmail.com, velikii-1@yandex.ru ( $\square$ corresponding author);

${ }^{2}$ Timiryazev Russian State Agrarian University-Moscow Agrarian Academy, 49, ul. Timiryazevskaya, Moscow, 127550 Russia, e-mail m_selin@mail.ru

ORCID:

Mamontova T.V. orcid.org/0000-0001-8799-3268

Selionova M.I. orcid.org/0000-0002-9501-8080

The authors declare no conflict of interests

Received March 23, 2021

Aybazov A.-M.M. orcid.org/0000-0002-3704-3210

doi: 10.15389/agrobiology.2021.4.752eng

\section{Abstract}

Sheep (Ovis aries) are polyestrous animals with a distinct breeding season. Long artificial selection has minimized the impact of seasonal environmental factors on the sheep reproductive function. The seasonality of reproduction is practically not characteristic of sheep bred near the equator but is well pronounced in the middle and high latitudes. The basic strategy of sheep breeding in Russia is production of young mutton and lamb. As Russia does not have its own gene pool of highly productive specialized meat breeds, the use of the best alien breeds is inevitable. However, experimental data on the reproductive performance of alien meat rams under the conditions of the Central zone of the Stavropol territory is practically absent. Our study aimed to examine sexual activity and sperm production in meat sheep in different seasons in the Central zone of the Stavropol territory. During the breeding (autumn) and non-breeding (winter, spring, and summer) seasons, sperm samples were taken from Charolais rams $(n=8)$ and Ile-de-France rams $(n=5)$ using an artificial vagina. The rams of both breeds showed significant seasonal variation in their sexual activity and sperm production. In winter, the sexual activity of the rams decreased and the time required for the expression of the entire complex of sexual reflexes increased. Compared to autumn, the time of receiving ejaculate from Charolais sheep increased 1.70 times in winter, 2.56 times in spring, and 2.62 times in summer. The Ilede-France rams showed similar dynamics, but a decrease in sexual activity was less pronounced compared to the Charolais rams. Ile-de-France rams took longer to ejaculate (1.09 times in winter, 1.62 times in spring, and 1.78 times in summer compared to breeding season). Sperm motility in Charolais rams varied from 9.1 points in breeding season to 7.4 points in spring. In winter and summer, the motility was 8.5 and 8.1 points, respectively. The volume of ejaculate and sperm cell concentrations showed similar patterns, being the highest in autumn, the lowest in spring, and intermediate in summer and winter. In autumn, Ile-de-France rams produced the largest volume of ejaculate with maximum concentration and the highest motility of sperm cells, i.e., $1.15 \mathrm{ml}, 3.75$ billion/ml, 8.57 points vs. $0.98 \mathrm{ml}, 3.38$ billion/ml, 7.95 points in winter, $0.88 \mathrm{ml}, 2.85$ billion/ml, 7.55 points in spring, and $0.96 \mathrm{ml}, 3.15$ billion/ml, 8.19 points in summer. Microstructural analysis detected sperm cells with an intact acrosome ranging from $65 \%$ in summer in Charolais rams to $82 \%$ in autumn in Ile-de-France rams. Therefore, despite significant seasonal variations, Charolais and Ile-de-France rams can produce high-quality semen both in breeding and non-breeding seasons under the climatic conditions of the Central zone of the Stavropol territory.

Keywords: rams, breeding and non-breeding season, sexual activity, quality of semen. 